\title{
Upaya Pemberdayaan Subak Umabun sebagai Lembaga Agribisnis di Desa Angantaka Kecamatan Abiansemal Kabupaten Badung
}

\author{
DEWA PUTU ALIT SUDIRA, NI WAYAN SRI ASTITI, \\ I GEDE SETIAWAN ADI PUTRA
}

\author{
Program Studi Agribisnis Fakultas Pertanian Universitas Udayana \\ Jalan P.B. Sudirman Denpasar 80232 \\ E-mail: dewaalit31@yahoo.com \\ wayansriastiti@yahoo.co.id
}

\section{Abstract \\ Measuring Empowerment Subak Umabun As Agribusiness Board at Village Angantaka Abiansemal Badung District.}

Research efforts empowerment subak as agribusiness board aims to boost the economy and the welfare of farmers, so that the culture of agriculture demand and not abandoned by society, particularly Subak Umabun. This study aims to (1) identify the potential Subak Umabun related to natural resources, human resources and financial resources, (2) To know the efforts made to empower the board to Subak Umabun agribusiness. This research was conducted at Subak Umabun, the number of respondents 75 people appointed by the formula slovin, data that is used structured interviews and in-depth interviews. The results showed that the potential of Subak Umabun aspects of natural resources, human resources and financial resources are classified with an average score of 3,19. Further empowerment undertaken by Subak Umabun are classified by score of 3,21 . And the last institution in agribusiness Subak Umabun high achievement score of 3,68. Based on these results, it is recommended to the government through the Department of Agriculture, Plantation and Forestry Badung need to deepen the study of this kind, so that the programs formulated by the government not only in the form of social assistance

Keywords: subak, empowerment, rice, agribusiness

\section{Pendahuluan}

\subsection{Latar Belakang}

Subak sebagai lembaga irigasi tradisional di Bali sudah ada sejak hampir satu millennium. Subak tidak lepas dari kegiatan irigasi untuk bercocok tanam padi, maka tidak keliru jika dikatakan bahwa subak identik dengan budidaya padi/budaya padi/rice culture. Keunikan subak terlihat dalam hal pelaksanaan kegiatan ritual keagamaan yang 
sangat padat dan terkait erat dengan tahap-tahap pertumbuhan tanaman padi. Kegiatan ritual inilah yang merupakan ciri khas subak dan membedakannya dengan sistem irigasi tradisional lainnya di dunia. Memang tepat jika dikatakan bahwa subak selama ini merupakan lembaga irigasi tradisional yang bercorak sosioagraris religious.

Subak tetap eksis sampai sekarang ini kiranya cukup membuktikan bahwa subak adalah lembaga yang viable atau tangguh. Namun dewasa ini kelestarian subak rupanya mulai terancam. Hal ini disebabkan oleh lingkungan strategis subak, yang sudah banyak berubah sebagai akibat dari gencarnya pelaksanaan program-program pembangunan di berbagai bidang beserta derasnya arus globalisasi yang kini melanda hampir setiap penjuru dunia.

Pelestarian subak penting untuk keberlanjutan subak dan pemanfaatan sumberdaya air di Bali yang berlandaskan THK (Tri Hita Karana) sebagai institusi adat pendayagunaan air. Pertambahan jumlah penduduk, peningkatan kesejahteraan masyarakat, dan berkembangnya sektor-sektor lain di luar sektor pertanian menyebabkan kebutuhan air semakin meningkat.

Beberapa upaya yang dapat dilakukan untuk mewujudkan subak yang lestari dan tangguh dalam mendukung keberlanjutan pembangunan pertanian selain melalui "Green Tourism", yaitu ; 1) membatasi alih fungsi lahan, 2) mengurangi kesenjangan ekonomi antara daerah pedesaan dan perkotaan atau antara petani, dan 3) memperkuat/memberdayakan kelembagaan subak.

Subak Umabun merupakan salah satu subak yang berada di wilayah administratif Desa Angantaka, Kecamatan Abiansemal, Kabupaten Badung, yang diharapkan mampu melaksanakan kegiatan agribisnis. Mengetahui pelaksanaan sistem dan subsistem agribisnis di Subak Umabun diperlukan penelitian yang berkaitan dengan pelaksanaan sistem dan subsistem dari usaha agribisnis, dan masalah-masalah yang dihadapi dalam pelaksanaan agribisnis, serta solusi pemberdayaan dan subak sebagai pelaku usaha agribisnis.

\subsection{Rumusan Masalah}

Berdasarkan latar belakang yang telah dipaparkan di atas, maka dapat dirumuskan permasalahan sebagai berikut, apa potensi yang dimiliki Subak Umabun untuk diberdayakan menjadi lembaga agribisnis yang berhubungan dengan sumber daya alam, sumber daya manusia dan sumber daya finansial, dan apa upaya yang dilakukan untuk memberdayakan Subak Umabun sebagai lembaga agribisnis.

\subsection{Tujuan Penelitian}

Tujuan penelitian ini adalah untuk mengetahui potensi yang dimiliki Subak Umabun yang berhubungan dengan sumber daya alam, sumber daya manusia dan sumber daya finansial dan untuk mengetahui upaya yang dilakukan untuk memberdayakan subak Umabun sebagai lembaga agribisnis. 


\section{Metode Penelitian}

\subsection{Lokasi dan Waktu Penelitian}

Penelitian dilaksanakan di Subak Umabun yang beralamat di Desa Angantaka, Kecamatan Abiansemal, Kabupaten Badung. Penelitian ini dilaksanakan pada bulan Maret 2016 sampai Juni 2017. Pemilihan kawasan ini sebagai lokasi penelitian dilakukan secara sengaja (purposive).

\subsection{Penentuan Populasi dan Sampel}

Populasi dari penelitian ini adalah anggota Subak Umabun yang berjumlah 295 orang (anggota aktif). Penentuan ukuran sampel dalam penelitian ini dengan menggunakan rumus Slovin sehingga jumlah responden yang diambil menjadi 75 orang.

\subsection{Teknik Pengumpulan Data, Instrumen Pengumpulan Data, Variabel Penelitian, dan Metode Analisis}

Teknik pengumpulan data yang digunakan yaitu teknik observasi dan wawancara. Instrumen penelitian data yang digunakan adalah dengan memberikan pertanyaan atau pernyataan tertulis untuk mendapatkan informasi dari responden (Gulo, 2002). Variabel pada penelitian ini adalah potensi Subak Umabun, upaya pemberdayaan Subak Umabun, dan kelembagaan agribisnis di Subak Umabun. Metode analisis yang digunakan adalah data kuantitatif dan data kualitatif.

\section{Hasil dan Pembahasan}

\subsection{Karakteristik Responden}

Karakteristik responden dalam penelitian ini meliputi umur, tingkat pendidikan formal, mata pencaharian, jumlah anggota rumah tangga, dan luas lahan garapan.

\subsubsection{Umur}

Dikemukakan oleh Elisabeth B.H (1997), usia adalah umur yang diukur dengan tahun dan lamanya hidup dalam tahun dihitung sejak dilahirkan. Pendapat lain, dinyatakan oleh Dewi dan Wawan (2010) semakin cukup umur, tingkat kematangan, dan kekuatan seseorang akan lebih matang dalam berpikir dan bekerja.

Menurut Biro Pusat Statistik (Darmada, 2011), penggolongan umur di bawah 15 tahun dan di atas 64 tahun dikelompokkan ke dalam umur non produktif sedangkan penduduk yang dikelompokkan ke dalam umur produktif, yaitu antara umur 15 tahun sampai dengan 64 tahun. Hasil penelitian menunjukkan bahwa umur responden lebih banyak berada pada usia produktif yaitu sebanyak 57 orang (76\%). Hal ini berarti bahwa responden menerima pengetahuan atau informasi baru untuk memperbaiki usahataninya, dalam hal ini tentang pemberdayaan Subak Umabun menjadi lembaga agribisnis.

\subsubsection{Tingkat pendidikan formal}

Tingkat pendidikan yang memadai membuat petani akan semakin mengerti dan memahami materi-materi yang disampaikan oleh penyuluh serta mempengaruhi 
kemampuan petani untuk menerima inovasi baru (Thoha, 2004). Berdasarkan hasil penelitian, dilihat dari tamatan sekolah dasar ( SD ) dan tamatan sekolah menengah pertama ( SMP ) yang dienyam responden lebih banyak, yaitu sebanyak 38 orang $(50,66 \%)$ dari pada responden yang mengenyam pendidikan SMA dan Perguruan Tinggi yang hanya 35 orang $(46,66 \%)$, dan responden yang sama sekali tidak mengenyam pendidikan sebanyak dua orang $(2,66 \%)$.

\subsubsection{Mata pencaharian}

Berdasarkan hasil penelitian, dapat diketahui mata pencaharian pokok terbanyak responden sebagai petani sebanyak 36 orang (48\%), dan 39 orang lainnya (52\%) memiliki pekerjaan pokok sebagai PNS, pekerja bangunan, dan pengrajin.

\subsubsection{Jumlah anggota rumah tangga}

Berdasarkan hasil penelitian, sebanyak 43 responden rumah tangga $(57,33 \%)$ termasuk kelompok dengan jumlah anggota rumah tangga antara empat sampai dengan lima orang, sebanyak 22 rumah tangga $(29,34 \%)$ dengan jumlah anggota rumah tangga antara enam sampai dengan tujuh orang, dan 10 rumah tangga (13,33\%) yang beranggotakan dua sampai dengan tiga orang. Secara keseluruhan jumlah tanggungan responden sebanyak 344 orang, jika dirata-ratakan antara jumlah tanggungan responden dengan jumlah responden maka didapat anggota dalam satu rumah tangga sebanyak lima orang.

\subsection{Potensi Subak Umabun}

Subak Umabun yang akan dibahas yaitu, potensi sumber daya alam (SDA), potensi sumber daya manusia (SDM), dan potensi sumber daya finansial (SDF).

\subsubsection{Sumber daya alam ( SDA)}

Potensi sumber daya alam ( SDA ) tergolong sedang dengan pencapaian skor sebanyak 3,34. Kategori sumber daya alam (SDA) tergolong sedang karena air irigasi di Subak Umabun belum tersedia dengan baik, hal ini berdampak pada hasil pertanian yang kurang memuaskan, selain itu kondisi tanah pertanian di Subak Umabun juga juga tidak begitu subur, hal ini menyebabkan hasil dari pada pertanian di Subak Umabun ini tidak maksimal.

Subak Umabun termasuk wilayah Desa Angantaka, Kecamatan Abiansemal, Kabupaten Badung, dengan batas-batas sebagai berikut. Adapun batas-batas Subak Umabun adalah : sebelah utara berbatasan dengan Desa Angantaka, sebelah timur berbatasan dengan sungai, sebelah selatan berbatasan dengan Desa Penatih dan sebelah barat berbatasan dengan sungai. Luas Subak Umabun adalah 88 Ha, Subak Umabun dibagi menjadi lima munduk, yaitu Munduk Kapat, Munduk Kesanga, Munduk Gaduh, Munduk Sampit, dan Munduk Teba. Subak Umabun merupakan Pasedahan Yeh Penet, jadi sumber air irigasinya berasal dari Sungai Ayung. Tanah yang akan ditanami padi diolah sesuai dengan petunjuk PPL sehingga padi tumbuh mencapai perkembangan yang maksimal atau tumbuh subur. Bibit yang ditanam berupa bibit jenis padi lokal 
seperti IR 64 Ceherang, Mansur, dan Padi Serang. Pola tanam yang biasa dilakukan petani di Subak Umabun menggunakan pola tanam padi-padi-palawija dengan sistem tanam serempak, selama tanah sawah ditanami palawija, petani menanam berbagai jenis tanaman seperti tanaman jagung, kacang, tomat, bunga pacah, agar tanah sawah mereka tidak kosong, karena menurut petani, walaupun tanah ditanami palawija, tidak mengurangi unsur hara yang terkandung dalam tanah dan dapat meningkatkan produktivitas tanah dan meningkatkan pendapatan sehingga dapat mensejahterakan petani dan keluarganya. Tanaman padi merupakan tanaman pertanian utama yang diusahakan petani di Subak Umabun.

\subsubsection{Sumber daya manusia ( SDM)}

Potensi sumber daya manusia (SDM) tergolong sedang dengan pencapaian skor sebesar 3,33. Kategori sedang ini didapat karena rata-rata petani anggota Subak Umabun siap/sanggup menjadi anggota kelembagaan agrbisnis, Tingkat pendidikan anggota Subak Umabun sudah cukup baik karena sebagian petani sudah pernah mengenyam pendidikan minimal sembilan tahun, pendidikan merupakan salah satu faktor yang mendorong kemampuan petani untuk menyerap teknologi dan ilmu pengetahuan. Tingkat pendidikan yang memadai membuat petani akan semakin mengerti dan memahami materi-materi yang disampaikan atau dianjurkan oleh penyuluh serta mempengaruhi kemampuan petani untuk menerima dan mencoba inovasi baru (Thoha, 2004). Hal ini juga berarti, semakin tinggi tingkat pendidikan petani, maka semakin baik pula kemampuan petani dalam menerima suatu pengetahuan yang baru, khususnya mengenai upaya pemberdayaan subak sebagai lembaga agribisnis.

\subsubsection{Sumber daya finansial (SDF)}

Padi merupakan tanaman yang paling dominan di Subak Umabun sesuai pola tanam mengusahakan tanaman padi dua kali setahun, rata-rata produktivitas dalam setahun $67 \mathrm{Kw} / \mathrm{Ha}$ gabah kering giling sedangkan untuk produktivitas kedele rata-rata $14,7 \mathrm{Kw} / \mathrm{Ha}$, dari analisa usaha tani didapatkan bahwa pendapatan petani dari usaha padi selama satu tahun sebesar Rp. 31.500.000,00 dan dari usaha tani kedelai petani mendapat pendapatan sebesar Rp.9.500.000,00 per Ha, jadi pendapatan petani selama setahun dalam usaha tani satu Ha sebanyak Rp. 41.000.000,00 . Dilihat dari rata-rata luas garapan $(0,434 \mathrm{Ha})$ didapatkan rata-rata pendapatan petani di Subak Umabun dalam setahun sebanyak Rp. 17.794.000,00, dari data ini, pendapatan petani dan usahatani padi dan kedelai di Subak Umabun rata-rata di setiap bulan sebanyak Rp. 1.482.833,00.

Potensi sumber daya finansial (SDF) tergolong sedang dengan pencapaian skor sebanyak 3,19. Kategori sedang ini didapat karena modal/uang di koperasi di Subak Umabun ini sudah cukup efisien, namun petani yang memiliki status perekonomian yang sangat rendah sulit untuk mencari pinjaman, karena jaminan yang dimiliki petani untuk melakukan pinjaman sangat rendah. Alat pertanian di Subak Umabun ini juga terasa kurang karena keterbatasan alat pertanian. Hal ini yang menyebabkan proses dari 
produksi Subak Umabun ini menjadi kurang optimal. Jadi nilai rata-rata pencapaian skor dari potensi sumber daya dari Subak Umabun ini tergolong sedang dengan pencapaian skor rata-rata sebanyak 3,19.

\subsection{Upaya Pemberdayaan Subak Umabun sebagai Lembaga Agribisnis}

Adapun upaya-upaya dalam memberdayakan Subak Umabun sebagai lembaga agribisnis meliputi :

\section{a. Penerapan aturan yang mengikat di subak (awig-awig)}

Awig-awig merupakan suatu produk hukum dari orgnisasi tradisional di Bali, seperti subak yang dibuat secara musyawarah mufakat oleh seluruh anggotanya berdasarkan rasa keadilan dan rasa kepatuhan yang hidup di dalam masyarakatnya dan diberlakukan sebagai pedoman bertingkah laku sebagai pedoman keharmonisan. Awigawig ini sebenarnya merupakan anggaran dasar subak sebagai anggaran rumah tangganya dalam berupa pararem.

Awig-awig dalam Subak Umabun merupakan seperangkat aturan-aturan yang memuat tentang ketentuan-ketentuan tentang ketentuan-ketentuan yang harus dilakukan atau yang tidak boleh dilakukan oleh seluruh anggota subak termasuk juga pengurus subak. Berdasarkan hasil wawancara terhadap responden subak diperoleh informasi bahwa setiap anggota subak wajib mematuhi aturan-aturan yang termuat dalam awigawig yang ada di Subak Umabun.

Beberapa aturan penting yang tertuang dalam awig-awig subak meliputi : Distribusi dan alokasi air irigasi, penetapan pola tanam dan jadwal tanam, pengelolaan keuangan subak, peraturn pelaksanaan rapat, kegotong-royongan petani anggota subak, dan penyelenggaraan usaha bisnis. Selain aturan-aturan yang ada, kekuatan dari awigawig di Subak Umabun adalah dengan adanya sanksi seperti teguran dan penutupan haknya untuk memperoleh air, hal ini dikenakan kepada petani anggota Subak Umabun termasuk pengurus yang melanggar peraturan yang ada. Adanya pemanfaatan air irigasi secara bersama-sama merupakan salah satu faktor pengikat diantara anggota subak sekaligus sebagai kekuatan yang harus diatur pengolahanya melalui penerapan awigawig.

Adanya awig-awig bagi para petani dapat berusahatani secara kompak melalui jenis pilihan tanaman, varietas tanaman, dan jadwal penamanan akan memberikan suatu kekuatan bagi subak untuk mengusahakan kegiatan bisnis. Dengan demikian kegiatan bisnis yang dapat dikembangkan sehubungan dengan pilihan varietas ini diantaranya adalah penyediaan sarana produksi seperti benih, bibit, pupuk, dan obat-obatan, sehingga subak dapat mengusahan sendiri atau memiliki usaha bisnis dalam penyediaan kebutuhan sarana produksi pertanian yang nantinya akan memberikan penerimaan bagi subak. Ini berarti bahwa terdapat suatu kekuatan di dalam yang dapat dimaksimalkan sehingga pengelolaan usahatani yang berorientasi agribisnis dapat ditingkatkan. 


\section{b. Pengadaan infrastuktur yang memadai}

Subak Umabun memiliki sarana dan prasarana yang memadai yang didukung dengan adanya fasilitas jalan menuju Subak Umabun sangat mudah diakses oleh transportasi roda dua maupun roda empat sehingga menjadi kekuatan yang harus dimamfaatkan untuk membangkitkan ekonomi kerakyatan anggota subak. Saluran air irigasi yang ada pada pembagian air irigasi atar munduk juga termasuk irigasi teknis dimana sudah memakai beton untuk menghindari permasalahan antar munduk dalam pemakaian air yang sudah diperhitungkan berdasarkan luas lahan.

Koordinasi juga dipermudah pada Subak Umabun dengan adanya balai subak yang dipergunakan sebagai tempat untuk pertemuan antar anggota guna membahas segala sesuatu untuk kepentingan subak. Subak Umabun juga memiliki Pura Dugul atau Pura Subak dimana digunakan untuk kepentingan ritual keagamaan yang berhubungan dengan penanaman padi. Adanya sarana dan prasarana ini dapat meningkatkan interaksi antara anggota-anggota dan menjadi ajang tukar informasi antara anggota sehingga dapat meningkatkan motivasi untuk bersaing positif dalam berusahatani.

\section{c. Pengembangan terhadap agribisnis}

Sikap petani yang dimaksud adalah suatu kecenderungan yang terdapat dalam diri individu-individu petani anggota subak terhadap pengembangan agribisnis melalui organisasi subaknya, dimana aspek yang mencakup mengenai arti dan tujuan agribisnis, teknologi budidaya pertanian, penggunan sarana produksi pertanian, pilihan jenis pertanian dan varietas, pasca panen, dan pengumpulan pengelolaan modal usahatani. Hasil wawancara dengan para petani yang ada di Subak Umabun menunjukan bahwa para petani memiliki sikap yang positif terhadap kegiatan agribisnis yang dilakukan melalui organisasi subaknya yang dapat menjadi salah satu kekuatan yang terdapat dalam kondisi internal Subak Umabun. Sumber manusia yang ada di Subak Umabun terindikasikan bahwa terdapat suatu dorongan dalam diri petani untuk mengembangkan agribisnis. Kekuatan dalam wujud sikap yang positif terhadap agribisnis ini perlu ditingkatkan seperti dengan faktor-faktor lainnya seperti peningkatan pengetahuan dan keterampilan petani dalam pengembangan agribisnis.

\section{d. Adanya rapat rutin untuk mempererat hubungan anggota subak}

Pertemuan rutin yang dilakukan di Subak Umabun atau yang biasa disebut sangkepan dilakukan setiap sebulan sekali. Penentuan hari sangkepan ini dilakukan melalui kesepakatan diantara petani anggota subak dan pengurus yang pada hari itu dianggap sebagai hari baik. Berdasarkan wawancara yang dilakukan diperoleh informasi bahwa kegiatan ini wajib diikuti oleh seluruh petani anggota subak, kecuali anggota subak yang memiliki halangan seperti adanya upacara agama dan sedang terkena musibah. Petani anggota subak yag berhalangan hadir pada saat pertemuan rutin atau sangkepan akan memberikan keterangan atau informasi sebelum ketidakhadirannya. 
Pertemuan rutin ini diselenggarakan untuk beberapa acara, seperti membahas mengenai program-program pemerintah mengenai pertanian, iuran-iuran, pemanfaatan air irigasi, masalah-masalah yang dihadapi oleh para petani dan memecahkan masalahmasalah yang ada, selain itu pada pertemuan rutin ini atau sangkepan ini juga membahas mengenai persiapan upacara keagamaan jika akan dilakukan penyelenggaraanya. Pertemuan rutin atau sangkepan merupakan salah satu kekuatan yang dimiliki angota subak untuk terwujudnya kekompakan antar anggota subak dalam pengambilan keputusan-keputusan yang berkenan dengan pengolahan usahatani di subak. Pengaturan pola jadwal tanam, pilihan varietas dapat diputuskan melalui pertemuan rutin ini, dengan demikian adanya pertemuan rutin ini merupakan salah satu komponen kekuatan yang perlu dipertahankan oleh Subak Umabun dalam kaitannya memberdayakan subak menjadi lembaga agribisnis.

\section{Simpulan dan Saran}

\subsection{Simpulan}

Berdasarkan hasil peneiltian dan pembahasan dapat disimpulkan sebagai berikut.

1. Hasil penelitian menunjukan bahwa potensi Subak Umabun, potensi sumber daya alam (SDA) tergolong sedang dengan pencapaian skor sebesar 3,34. Potensi sumber daya manusia (SDM) tergolong sedang dengan pencapaian skor sebesar 3,33. Potensi sumber daya finansial (SDF) tergolong sedang dengan pencapaian skor sebesar 3,19.

2. Adapun upaya pemberdayaan Subak Umabun tergolong dalam kategori sedang dengan rata-rata pencapaian skor sebesar 3,21. Adapun upaya yang dilakukan adalah melalui diklat tergolong tinggi dengan pencapaian skor sebesar 3,71. Upaya penyuluh tergolong tinggi dengan pencapaian skor sebesar 3,50. Diskusi tergolong sedang dengan pencapaian skor sebesar 2,97. Motivasi petani dalam memberdayakan subak tergolong tinggi dengan pencapaian skor sebesar 3,46. Memberikan fasilitas kepada anggota subak tergolong rendah dengan pencapaian skor sebesar 2,56.

\subsection{Saran}

Bagi pemerintah melalui Dinas Pertanian, Perkebunan, dan Kehutanan Kabupaten Badung perlu memperdalam penelitian sejenis ini, sehingga program-program yang dirumuskan oleh pemerintah tidak semata-mata berupa bantuan sosial, kurang mendidik, bersifat sementara, dan tidak mampu memberdayakan subak. Harapan penulis bagaimana cara pemerintah merumuskan program-program yang mampu memberdayakan subak, yang pada akhirnya subak mempunyai daya saing dalam pembangunan berbasis agribisnis serta berkelanjutan.

Anggota subak sebagai pelaku sebaiknya berani dalam mencoba teknologi dalam bidang pertanian yang diberikan oleh penyuluh, karena dengan mencoba petani akan lebih mendapat pengalaman baru untuk diterapkan pada usahataninya dimasa mendatang. 


\section{Ucapan Terima Kasih}

Penulis menyampaikan terima kasih kepada anggota subak yang telah memberikan data penelitian dan semua pihak yang telah membantu dan memberikan dukungan baik secara moril maupun dalam proses penyelesaian e-jurnal ini.

\section{Daftar pustaka}

Darmada, Ida Bagus Kade Dwi. 2011. Partisipasi Masyarakat dalam Upaya Pelestarian Mangrove Tanaman Hutan Raya Ngurah Rai. Skripsi tidak dipublikasikan. Program Studi Agribisnis, Fakultas Pertanian, Universitas Udayana Denpasar.

Dewi dan Wawan. 2010. Teori dan Pengukuran Pengetahuan, Sikap, dan Perilaku Manusia. Nuha Medika. Yogyakarta.

Elisabeth, B.H. 1997. Psikologi Perkembangan Suatu Pendekatan Sepanjang Rentang Kehidupan. Erlangga, Jakarta.

Erianto.2009. Pupuk Organik dan Keuntungannya. [Jurnal Online]. Internet. http://eriantosimalongo.wordpress.com.Diunduh Tanggal 20 Maret 2015.

Gulo, W. 2002. Metode Penelitian. Gramedia Widiasarana Indonesia. Jakarta.

Kurnia, R. 2004. Laporan Kegiatan Kursus Identifikasi Dampak Lingkungan. GEGAMA, Yogjakarta.

Profil Desa Angantaka. 2015: Kelurahan Angantaka. Badung

Setiawan, C. 2013. Pengaruh Kualitas Produk, Harga,Saluran Disteribusi dan Periklanan Terhadap Keputusan Pembelian Konsumen Minuman Berkarbonat Merek Coca Cola (Studi Kasus Mahasiswa Fakultas Ekonomi Angkatan 2009 dan 2010). [Jurnal Online]. Internet. http://digilib.unpas.ac.id. Diunduh Pada Tanggal 10 Juni 2015

Sugiyono, 2010. Metode Penelitian Pendidikan: Pendekatan Kuantitatif, Kualitatif, dan $R \&$ D: Alfabeta. Bandung.

Thoha. 2004. Faktor yang Mempengaruhi Perkembangan Persepsi Seseorang. [Jurnal Online]. http://id.shvoong.com. Diunduh Tanggal 20 Desember 2015. 